ISSN 2413-0877 Volume 2 (2015) 317

The 3rd International Conference on Biological Science 2013

(The 3rd ICBS-2013)

\title{
THE EFFECT OF GLUCOSE AND LIGHT QUALITY ON SEED GERMINATION, VITAMIN E AND CHLOROPHYLL CONTENT OF GREEN BEAN SPROUT (Vigna radiata (L.) Wilcz.)
}

\author{
Kumala Dewi ${ }^{1}$ and Parmi ${ }^{2}$ \\ ${ }^{1}$ Fakultas Biologi, Universitas Gadjah Mada, Yogyakarta 55281, Indonesia \\ ${ }^{2}$ Madrasah Tsanawiyah Negeri Karangmojo, Kabupaten Gunung Kidul, DIY. \\ e-mail: k.dewi00000@lycos.com
}

\begin{abstract}
Environmental factors such as the existence of exogenous sugar and light quality during seed germination may affect the growth and quality of seedlings. This experiment was aimed to evaluate the effect of glucose and light quality on seed germination percentage, vitamine $\mathrm{E}$ and chlorophyll content in green bean sprout (Vigna radiata (L.) Wilcz). The experiment design used was $5 \times 5$ factorial. The main factor was glucose concentration which consisted of 5 levels $(0 \%, 0.5 \%, 1 \%, 2.5 \%$ or $5 \%)$. The second factor was variation of light quality which consists of 3 different light spectrums namely blue, red or green as well as sunlight and dark condition. Seeds were selected, sterilized and germinated in a petridish containing various level of glucose. Fourty seeds were germinated in each petridish and 5 replicates were used per treatment. Petridish with seeds in it were then placed in a growth chamber having different light quality (blue, red or green), under dark condition or light condition. Growth parameters observed were germination percentage and height of bean sprout. In addition, vitamine $E$ and chlorophyll conten were determined using spectrophotometer. Data were analyzed by using analysis of variance (ANAVA) and followed by Duncan's Multiple Range Test (DMRT) at significant level of $5 \%$. The results showed that increasing glucose content caused reduction in the germination percentage and height of bean sprouts whereas green and blue light also reduced seed germination. The vitamine $\mathrm{E}$ content in green bean sprout grown under red and blue light was relatively similar compared to those grown under sunlight or dark condition, however, green light decreased the vitamine $\mathrm{E}$ content in green bean sprout. In addition, the existence of glucose and light quality influenced chlorophyll content in green bean sprout.
\end{abstract}

Keywords : glucose, light quality, green bean, vitamine E, chlorophyll content.

ISSN 2413-0877 (c) 2015 The Authors.

Published by KnowledgeE Publishing Services This is an open access article under the CC BY-NC-ND license (http://creativecommons.org/licenses/by-nc-nd/4.0)

Selection and Peer-review under responsibility of the 3rd ICBS-2013

Doi http://dx.doi.org/10.18502/kls.v2i1.165 